\title{
Studies on processing technology and cost estimation of fig (Ficus carica L.) fruit powder enriched Burfi (Indian cookie)
}

\author{
A. P. Khapre*, P. N. Satwadhar and H. M. Syed \\ College of Food Technology, Vasantrao Naik Marathwada Krishi Vidyapeeth, Parbhani-431 402 (M.S.), INDIA \\ *Corresponding author. Email: khapreft@gmail.com
}

Received: January 22, 2015; Revised received: June 19,2015; Accepted: July 31, 2015

\begin{abstract}
The present article was designed with the aim to develop processing technology for preparation of fig (Ficus carica L.) fruits powder (Deanna variety) and the prepared fig powder was subsequently utilized in value added product like burfi (Indian cookie). In contrast to fig pulp and dried figs, the fig powder was found to be superior in terms of yield and ease of processing technology. Fig powder also open further fields of application that may promote fig powder processing at industrial scale in future. The products prepared by processing of figs viz. fig powder and fig burfi were chemically and sensorial assessed and also assessed for their economical feasibility and compared with market samples. Fig powder incorporated burfi was nutritionally rich in terms of fiber (3.7 \%), potassium $(0.464 \%)$ and protein $(13.12 \%)$. The prepared product was found to be low cost as compared to the similar market products.
\end{abstract}

Keywords: Cabinet dryer, Economic feasibility, Fig burfi , Fig powder

\section{INTRODUCTION}

Fig (Ficus carica L.) belongs to the family moraceae. The fig is a native of southern Arabia. In India, its commercial production is limited to a few centers in Maharashtra and south India. In Maharashtra, it is cultivated on commercial scale in adjoining areas of Pune and Aurangabad (Anonymous, 2012). As per the annual report of year 2013 given by Department of Agriculture, Maharashtra State assert that, the area under cultivation of fig fruits was 300 hectares up to 1990, which increased to 3715 hectares in 2013. Fig fruit is a rich source of nutrients such as dietary fiber and minerals like calcium and potassium. The edible fig is a powerhouse of nutrients and is known since the prehistoric times (Venu et al., 2005).

The fig, one of the most important fruit species in the Mediterranean area, bears fruits that are highly perishable, even in refrigerated conditions (Piga et al., 1995) and thus nearly all the world production is preserved in the dried form. Cabinet drying being considered the generic drying method followed for preparation of various food powders.

Among the confectionery, burfi is one of the most popular khoa-based sweet in all over the country. The generic nomenclature "burfi" covers a wide range of product variations that include plain, danedar, dudh, chocolate, fruit and coconut burfi. Typically, it has a mildly caramelized and pleasant flavour. Multi-layered and multi-coloured varieties are also produced (Varma et al., 2013).

Burfi has got unique sensory attributes which depend not only on the ingredients but also on processing conditions involved in their preparation. Generally, burfies are prepared by roasting the flour with or without fat, mixing it with sugar, vegetable oil and flavor and cooking it (Sharma et al., 2003). The development of fig burfi as an indigenous sweet meat prepared from fruit powder and khoa is an attempt to popularize the Indian sweet meats, which are now in demand for export to the western countries where a sizable Indian population. Keeping in view, the present study was conducted on processing technology and cost estimation of fig (Ficus carica L.) fruit powder enriched burfi (Indian cookie).

\section{MATERIALS AND METHODS}

Preparation of fig powder: Fresh ripened fig fruits of variety Deanna were obtained from the farmer's (Aurangabad district) fields. The fruits were washed, cleaned and used for the experiment. Firstly, fruits were cut into small shreds by using knife and shreds were spread on trays. Dry the shreds in Cabinet dryer at $60+5{ }^{\circ} \mathrm{C}$ temperature for $20-24 \mathrm{hrs}$. Pulverize/grind the dried shreds in the attrition mill and sieve the powder by using standard sieve of mesh size of 22 $\mathrm{BSS} / 0.71 \mathrm{~mm}$. In prepared fig powder $1 \%$ Tricalcium phosphate was added as an anticaking agent. Finally the prepared fig powder was packed into polyethylene bag and stored in cool and dry place.

Preparation of fig powder enriched Burfi: Twoliters of buffalo milk standardized to $6 \%$ fat in Karhai with stirring by Khunti in a circular motion. "Stirring-cum -scrapping" process continued till the pasty consistency 
(i.e. final stage of khoa formation) or directly utilize the khoa $(500 \mathrm{~g})$ instead of using milk. At temperature 88-90 ${ }^{\circ} \mathrm{C}$, sugar (at 30 per cent of Khoa) and fig powder (fig powder varying in proportion of 9,12 and 15 per cent) added into the khoa. Also added $25 \mathrm{~g}$ vegetable fat and food grade pink colour. Heated the mixture with stirring. Spread it in tray and cool. After setting, cut into rectangular pieces and packed it into butter paper and store it into cool and dry place.

Sensory evaluation: The sensory evaluation of fig burfi samples were examined by trained/semi-trained judges on nine point Hedonic scale for its color and appearance, taste, flavor, texture and overall acceptability (Amerine et al., 1965).

Chemical analysis: The fresh fig fruits, cabinet dried fig powder and fig burfies were analyzed for moisture, ash, T.S.S., pH, acidity, sugar, protein, fat, fiber, ascorbic acid and potassium by the methods given by AOAC (1990) and Ranganna (1995).

Statistical analysis: The data obtained on various parameters were recorded and statistically analyzed by Completely Randomized Design (CRD) as per the method proposed by Panse and Sukhatme (1967).

\section{RESULTS AND DISCUSSION}

Sensory Evaluation: The fig burfies prepared from different levels of fig powder ( 00 per cent i.e. control sample and 9, 12 and 15 per cent fig powder) were evaluated for their organoleptic properties. In the sensory evaluation, sample $S_{2}$ got maximum score (overall acceptability - 8.46) as compared to samples $\mathrm{S}_{0}, \mathrm{~S}_{1}$ and $\mathrm{S}_{3}$ which got score of $7.8,8.02$ and 8.12 respectively (Table 1). The sensory analysis of fig burfies showed that the best quality burfi with respect to sensorial parameter was obtained when the formulation contained $100 \mathrm{~g}$ fig powder, $500 \mathrm{~g}$ khoa, $170 \mathrm{~g}$ sugar and $25 \mathrm{~g}$ vegetable fat .

Chemical parameters of fig ( $F$. carica) fruit: The data pertaining to various chemical properties of fig fruit is depicted in Table 2.

The chemical composition results obtained in the present investigation revealed that the moisture content of fig fruit was 75.3 per cent. The dietary fiber content of fig fruit (Deanna cultivar) was found 1.34 per cent. The total acidity as citric acid content of Deanna cultivar was observed as 0.23 per cent against $\mathrm{pH}$ value of 5.4. It was also revealed that the fig contained $22^{\circ} \mathrm{Bx}$ total soluble solids. The values observed for reducing and non-reducing sugar content of Deanna cultivar was found to be 17.43 and 2.17 per cent respectively. The value of potassium content was found in fig fruit was $370 \mathrm{mg} / 100 \mathrm{~g}$. Similar results were reported by Polat and Caliskan (2008) for fig fruit of Deanna cultivar with very few acceptable variations with values given in the bracket indicate the results of present research work for easy comparison with past research. In their study, they concluded that fruit contained moisture 75.1 per cent (75.3), ash 1.06 per cent (1), TSS $22^{\circ} \mathrm{Bx}$
(22), acidity 0.21 per cent (0.23), pH 5.3 (5.4), total sugar 19.85 per cent (19.60), protein 1.68 per cent (1.75), fat 0.57 per cent (0.52), ascorbic acid 11.8 $\mathrm{mg} / 100 \mathrm{~g}$ (12.95), potassium $360 \mathrm{mg} / 100 \mathrm{~g} \mathrm{(370)}$ and dietary fiber 1.38 per cent (1.34).

Chemical parameters of fig $\boldsymbol{F}$. carica fruit powder: The data pertaining to various chemical properties of fig powder is depicted in Table 3.The results of chemical properties of fig powder indicated that the moisture content of fig powder was 10.43 per cent. The dietary fiber content of fig powder was found to be 15.41 per cent. So, the prepared fig powder was fiber rich and significant from nutritional point of view. The values observed for reducing and non-reducing sugar content of powder was found to be 55.41 and 6.11 per cent respectively. It was also observed that the protein content of powder was found to be 5.26 per cent. It was revealed that the ascorbic acid content of powder was found to be $5.12 \mathrm{mg} / 100 \mathrm{~g}$. The ascorbic acid content of powder was lower than that of fresh fruit due to loss of ascorbic acid during drying due to heat sensitivity of nutrient. The value of potassium found in fig powder was $2200 \mathrm{mg} / 100 \mathrm{~g}$ and therefore it is rich source of potassium. Similar results were also reported by Basavaraj et al. (2008) with very few considerable variations with values given in the bracket indicate the results of present research work for easy comparison with past research. In their study, they concluded that, fruit contained moisture 10.5 per cent (10.43), ash 4.02 per cent (3.9), acidity 1.27 per cent (1.40), pH 5.1 (5.05), total sugar 61.5 per cent $(61.52)$, protein 5.3 per cent (5.26), fat 2.47 per cent (2.48), ascorbic acid 5.8 $\mathrm{mg} / 100 \mathrm{~g}(5.12)$, potassium $2100 \mathrm{mg} / 100 \mathrm{~g} \mathrm{(2200)}$ and dietary fiber 15.22 per cent (15.41).

Chemical parameters of fig $\boldsymbol{F}$. carica Burfi: The mostly accepted sample of fig burfi was subjected to chemical analysis and the results obtained are presented in Table 3.The data pertaining to chemical properties of fig burfi reported that the burfi contained 23.5 per cent moisture and 3.7 per cent dietary fiber. The burfi also contained 72 per cent total soluble solids. It also reveals that the fig burfi contained reducing and non-reducing sugar 28.22 and 13.41 per cent respectively. Fig burfi was rich in protein and contained 13.12 per cent protein. Fat content of burfi was 20.02 per cent. The ascorbic acid decreased as compared to fresh figs and it was $3.09 \mathrm{mg} / 100 \mathrm{~g}$. The value of potassium found in burfi was $464 \mathrm{mg} / 100 \mathrm{~g}$. Similar results were also reported by Navaneetha et al. (2008) with very few acceptable variations with values given in the bracket indicate the results of present research work for easy comparison with past research. In their study, they concluded that, fruit contained moisture 22.88 per cent (23.5), ash 4.02 per cent (4.2), acidity 1.44 per cent (1.75), $\mathrm{pH} 4.3$ (4.26), total sugar 278.5 per cent (281.20), protein 12.88 per cent (13.12), fat 19.7 per cent (20.02), ascorbic acid $2.9 \mathrm{mg} / 100 \mathrm{~g}$ (3.09), potassium $452 \mathrm{mg} / 100 \mathrm{~g}$ (464) and dietary fiber 
Table 1. Sensory score of Fig Burfi as affected by addition of fig powder at different level (Values are means of three replicates in each case).

\begin{tabular}{cccccc}
\hline Sample & Color and Appearance & Taste & Flavor & Texture & Overall Acceptability \\
\hline $\mathrm{S}_{0}$ & 7.68 & 8.02 & 7.82 & 8.24 & 7.8 \\
$\mathrm{~S}_{1}$ & 7.98 & 8.22 & 7.82 & 8.08 & 8.02 \\
$\mathrm{~S}_{2}$ & 8.24 & 8.56 & 8.2 & 8.52 & 8.46 \\
$\mathrm{~S}_{3}$ & 7.96 & 8.32 & 8.06 & 8.2 & 8.12 \\
$\mathrm{SE} \pm$ & 0.07 & 0.05 & 0.08 & 0.09 & 0.1 \\
$\mathrm{CD}$ at 5\% & 0.22 & 0.16 & 0.25 & 0.27 & 0.3 \\
Level & & & & & \\
\hline
\end{tabular}

Table 2. Chemical composition of fresh fig (F. carica) fruit (Values are means of three replicates in each case).

\begin{tabular}{ccc}
\hline S. N. & Chemical Parameter & Measurement/Value \\
\hline 1. & Moisture $(\%)$ & 75.3 \\
2. & Ash $(\%)$ & 1.0 \\
3. & T.S.S. $\left({ }^{\circ} \mathrm{Bx}\right)$ & 22 \\
4. & Acidity (\%) (As citric acid) & 0.23 \\
5. & T.S.S. : Acid ratio & 95.65 \\
6. & pH & 5.4 \\
7. & Total sugar $(\%)$ & 19.60 \\
8. & Reducing sugar $(\%)$ & 17.43 \\
9. & Non-reducing sugar $(\%)$ & 2.17 \\
10. & Protein $(\%)$ & 1.75 \\
11. & Fat $(\%)$ & 0.52 \\
12. & Ascorbic acid $(\mathrm{mg} / 100 \mathrm{~g})$ & 12.95 \\
13. & Potassium $(\mathrm{mg} / 100 \mathrm{~g})$ & 370 \\
14. & Dietary Fiber $(\%)$ & 1.34 \\
\hline
\end{tabular}

Table 3. Chemical composition of Fig (F. carica) fruit powder and fig Burfi (Values are means of three replicates in each case).

\begin{tabular}{cccc}
\hline S. N. & Chemical Parameter & \multicolumn{2}{c}{ Measurement/Value } \\
\cline { 3 - 4 } & & Fig fruit powder & Fig Burfi \\
\hline 1. & Moisture (\%) & 10.43 & 23.5 \\
2. & Ash (\%) & 3.9 & 4.2 \\
3. & Acidity (\%) (As citric acid) & 1.40 & 1.72 \\
4. & pH & 5.05 & 4.26 \\
5. & Total sugar $(\%)$ & 61.52 & 281.20 \\
6. & Reducing sugar $(\%)$ & 55.41 & 6.7 \\
7. & Non-reducing sugar $(\%)$ & 6.11 & 13.41 \\
8. & Protein $(\%)$ & 5.26 & 13.12 \\
9. & Fat $(\%)$ & 2.48 & 20.02 \\
10. & Ascorbic acid $(\mathrm{mg} / 100 \mathrm{~g})$ & 5.12 & 3.09 \\
11. & $\beta$-Carotene $(\mu \mathrm{g} / 100 \mathrm{~g})$ & 46.05 & 52.87 \\
12. & Potassium $(\mathrm{mg} / 100 \mathrm{~g})$ & 2200 & 464 \\
13. & Dietary fiber $(\%)$ & 15.41 & 3.7 \\
\hline
\end{tabular}

Table 4. Production cost of $100 \mathrm{~kg}$ of fig (F. carica) powder.

\begin{tabular}{|c|c|c|c|}
\hline Particular & Quantity & Price per Unit in Rs. & Cost in Rs. (US US \$ ) \\
\hline Fig fruits & $555 \mathrm{~kg}$ & 60/kg (US US \$ 1 ) & $33300 /-($ US \$ 532.4) \\
\hline Chemicals (Anticaking agent) & $1 \mathrm{~kg}$ & Rs. 550/kg (US \$ 8.8) & Rs. 550/- (US \$ 8.8 ) \\
\hline Packaging material & 400 Bags & Rs. 2.5/Bag (US \$ 0.04 ) & Rs. 1000/- (US \$ 16 ) \\
\hline \multicolumn{3}{|l|}{ Total raw material cost } & Rs. 34850/- (US \$ 557.3) \\
\hline \multicolumn{3}{|c|}{ Processing cost@30\% of raw material cost } & Rs. 10455/- (US \$ 167.2) \\
\hline \multicolumn{3}{|c|}{ Production cost for $100 \mathrm{~kg}$ fig powder } & Rs. 45305/- (US \$ 724.5) \\
\hline \multicolumn{3}{|l|}{ Production cost of fig powder $/ \mathrm{kg}$} & Rs. $453.05 /-($ US $\$ 7.3)$ \\
\hline
\end{tabular}


Table 5. Production cost of $100 \mathrm{~kg}$ of fig (F. carica) Burfi.

\begin{tabular}{llll}
\hline Particular & Quantity & Price per Unit in Rs. (US \$ ) & Cost in Rs. (US \$ ) \\
\hline Fig powder & $12.50 \mathrm{~kg}$ & Rs. 453.05/kg (US \$ 7.3 ) & Rs. 5663.12/- (US \$ 90.5) \\
Sugar & $21.50 \mathrm{~kg}$ & Rs. 31/kg (US \$ 0.5) & Rs. 666.50/- (US \$ 10.7) \\
Khoa & $62.50 \mathrm{~kg}$ & Rs. 145/kg (US \$ 2.3) & Rs. 9062.50/- (US \$ 144.9) \\
Vegetable fat & $3.50 \mathrm{~kg}$ & Rs. 80/kg(US \$ 1.3) & Rs. 280/- (US \$ 4.5) \\
$\begin{array}{l}\text { Packaging material } \\
\text { Total raw material cost }\end{array}$ & 200 Boxes & Rs. 2/Box (US \$ 0.03) & Rs. 400/- (US \$ 6.4) \\
Processing cost @ 30 \% of raw material cost & & Rs. 16072.12/- (US \$ 257.) \\
Production cost for 100 kg fig Burfi & & Rs. 4821.636/- (US \$ 77.) \\
Production cost of fig Burfi/kg & & Rs. 20893.756/- (US \$ 334.) \\
\hline
\end{tabular}

3.58 per cent (3.7).

Production cost of fig ( $F$. carica) fruit powder: The cost of production of the fig powder (based on $1 \mathrm{~kg}$ of fresh figs) is given in Table 4.

The quantity of fresh fig fruits required for production of $100 \mathrm{~kg}$ of fig powder was $555 \mathrm{~kg}$ (as yield of fig powder was $18 \%$ ). Thus, the total raw material cost for preparation of $100 \mathrm{~kg}$ of fig powder was Rs. 34850/ - ( US \$ 557.3 ). The processing cost charges, which were applied at the rate of $30 \%$ of the raw material cost was Rs. 10455/- (US \$ 167.2 ). The total production cost of $100 \mathrm{~kg}$ fig powder was 45305/- (US \$ 724.5). Hence, for production of $1 \mathrm{~kg}$ of fig powder from fresh fig fruits, Rs. 453.05/- i.e. Rs. 453/- (US \$ 7.3) production cost was required.

Production cost of fig ( $F$. carica) Burfi: The mostly accepted fig burfi was accessed for its production cost. The cost of production of fig burfi (based on $1 \mathrm{~kg}$ of fresh figs) is given in Table 5 .

For the production of $100 \mathrm{~kg}$ of fig burfi, $12.50 \mathrm{~kg}$ of fig powder was required. The total ingredient cost for production of $100 \mathrm{~kg}$ of fig burfi was Rs. 16072.12/ - (US \$257), while the processing cost (applied at rate of 30 per cent of ingredient cost) was Rs. 4821.636/ - (US \$ 77). Thus, the production cost of $100 \mathrm{~kg}$ of fig burfi was Rs. 20893/- (US \$ 334). The production cost of fig burfi per $\mathrm{kg}$ was assessed as Rs. 208.93/- i.e. Rs. 209/- (US \$ 3.3).

Unit cost of production of fig ( $F$. carica) powder enriched fig Burfi: The unit cost of production of fig Burfi was Rs. 4.18 (US \$0.07) per piece of $20 \mathrm{~g}$ weight.

\section{Conclusion}

The above study revealed that, the fig powder prepared by cabinet drying method was utilized as a novel food ingredient for enrichment of burfi (Indian cookie). The value added products prepared by processing of fresh figs viz. fig powder and fig burfi were assessed for their cost of production as well as nutritional importance. Fig powder and its incorporated burfi were nutritionally rich in fiber, potassium and protein. The production cost of cabinet dried fig powder was Rs. 453.05/- (US $\$ 7.3$ ) per $1 \mathrm{~kg}$ and fig burfi (Rs. 4.18 per piece or Rs. $208.93 /$ - per $1 \mathrm{~kg}$ ) (US \$ 0.07 per piece or US $\$ 3.3$ per $1 \mathrm{~kg})$. These production costs were compared with similar products available in the market at present (fig burfi at Rs. 8.00 per piece or Rs. 450/- per $1 \mathrm{~kg}$ ) (US \$ 0.1 per piece or US $\$ 7.2$ per $1 \mathrm{~kg}$ ). However, comparison with market products showed that fig powder incorporated burfies were far cheaper and also they were rich in nutrients.

\section{REFERENCES}

Amerine, M.A., Pangborn, R.M. and Rossler, E.B. (1965). Principles of sensory evaluation of food. Academic Press Inc., New York.

Anonymous (2012). Survey of Fruits. Directorate of Horticulture, M. S. Pune.

AOAC (1990). Official Methods of Analysis. Association of Official Analytical Chemists, Washington D.C.

Basavaraj, M., Prabhu Kumar, G.P. and Sathyanarayana Reddy, B. (2008). Determination of drying rate and moisture rate of fig fruit (Ficus carica L.) by thin layer hot air drying method, J. Food Sci. and Technol., 45(1): 94-96.

Navneetha, R., Roopa, K.S. and Natarajan (2008). Quality of Khoa-Burfi prepared using different low calorie artificial sweeteners, Indian Food Packer, 56(4): 41-52.

Panse, V.S. and Sukhatme, P.V. (1967). Statistical Methods for Agricultural Workers. Indian Council of Agricultural Research, New Delhi. 70-72.

Piga, A., D’Aquino, S., Agabbio, M. and Pappoff, C. (1995). Influenza del confezionamento con film plastici sulla conservazione del fico. Italus Hortus, (2): 3-7.

Polat, A.A. and Caliskan, O. (2008). Fruit characteristics of table fig (Ficus carica L.) cultivars in subtropical climate condition of the Mediterranean region. New Zealand J. of Horticultural Science, (36): 107-115.

Ranganna, S. (1995). Handbook of Analysis and Quality Control for Fruit and Vegetable Products. Second Edition. Tata Mc. Graw Hill Pub. Co. Ltd., New Delhi.

Sharma, G.K., Semwal, A.D., Mahesh, C., Murthy, M.C.N. and Roopa, N. (2003). Development and storage stability of Moong dhal Burfi. Indian Food Packer, 38(2):69-73.

Varma, T., Singh, J., Ram Niwas, Singh, D., Gautam, A.K. and Kumar, S. (2013). Impact of feeding soy enriched burfi on the internal body parts of the albino rats. International Journal of Agricultural Sciences, 3(6): 550-552.

Venu, D.K., Munjal, S.V., Waskar, D.P., Patil, S.R. and Kale, A.A. (2005). Biochemical changes during growth and development of fig (Ficus carica L.) fruits. J. Food Sci. and Technol., 42(3):279-282. 